\title{
Energy transition in Russia
}

\author{
Tatiana Mitrova $^{1} \cdot$ Yuriy Melnikov ${ }^{1}$
}

Received: 29 April 2019 / Accepted: 28 August 2019 / Published online: 11 September 2019

(c) The Author(s) 2019

\begin{abstract}
This article provides an overview of Russian energy policy in the context of the global energy transition. Russia, ranking fourth in the world in primary energy consumption and carbon dioxide emissions, adheres to the strategy of "business as usual" and relies on fossil fuels. Decarbonization of the energy sector is not yet on the horizon: a skeptical attitude towards the problem of global climate change prevails among stakeholders. GDP energy intensity remains high, supported by relatively low energy prices and high cost of capital. The share of solar and wind energy in the energy balance is insignificant and is not expected to exceed $1 \%$ by 2040 . The challenge for Russia in the coming years is to develop a new strategy for the development of its energy sector, which enters a zone of high turbulence-even in the absence of the influence of the climate change agenda—due to increasing global competition, growing technological isolation, and financial constraints.
\end{abstract}

Keywords Energy transition $\cdot$ Russia $\cdot$ Energy policy $\cdot$ Energy efficiency $\cdot$ Renewables $\cdot$ Fossil fuels

\section{Introduction}

Energy transition, in a broad sense, can be defined as the next, or fourth, in a series of similar fundamental structural transformations of the global energy sector. Smil [1] distinguishes the first energy transition-from biomass to coal-within which the share of coal in the energy balance increased from 5 to $50 \%$ during the period from 1840 to 1900. The second energy transition is associated with the spread of oil-its share rose from $3 \%$ in 1915 to $45 \%$ in 1975 — and the third led to the partial displacement of both coal and oil by natural gas (with the growth of its share from $3 \%$ in 1930 to $23 \%$ in 2017). In all these transitions, the economic efficiency or availability of new energy sources compared with old sources played an important role. Today we are witnessing the beginning of the fourth energy transition: the share of renewables (without hydro) as a percentage of total primary energy consumption was $3 \%$ in 2017 , but it is expanding very quickly. In this fourth energy transition, unlike the previous three, a new driver is becoming critically important_combating global climate change-which

Tatiana Mitrova

Tatiana_Mitrova@skolkovo.ru; mitrovat@me.com

1 Moscow School of Management SKOLKOVO, Energy

Centre, Novaya Ul. 100, Skolkovo Village, Odintsovsky

District, Moscow 143025, Russia results in the establishment of compulsory energy sector decarbonization targets.

In a narrower sense, energy transition is a translation of the German term "Energiewende", which came into international use in the early 2010s after the accident at the Fukushima nuclear power plant. As one of the most ambitious $[2,3]$ decarbonization projects at a national scale (reduction in greenhouse gas [GHG] emissions of $40 \%$ by 2020 and $80-95 \%$ by 2050 from 1990 levels), the Energiewende is an example of large-scale climate-driven energy sector transformation.

Today, energy transition is driven by a complex of different drivers: the climate agenda, technological progress and the availability of new technology solutions able to dramatically increase the efficiency of the energy sector and transform its traditional way of functioning, the desire among all countries to ensure the competitiveness of their national economies and boost their development of affordable energy, and last but not least, the need to increase energy security. Achieving these objectives involves addressing the three pillars of the energy transition-the so-called three D's: decarbonization, decentralization, and digitization. This commonly used schematization provides a convenient instrument with which to assess the depth of energy transition penetration in different countries, including the Russian Federation. 
Russia is quite an important player in the global energy system: with just $3 \%$ of the global gross domestic product (GDP) and $2 \%$ of the global population, it provides $10 \%$ of global primary energy production, $5 \%$ of global primary energy consumption, and $16 \%$ of international energy trade [4]. Russia is the world's largest exporter of energy resources (\#2 for oil exports, \#1 for gas exports, and \#3 for coal exports in 2017, according to BP and the International Energy Agency [IEA] [5, 6]). It ranks fourth in the world - after China, the USA, and India_-in primary energy consumption, production of electricity, and carbon dioxide emissions due to the utilization of oil, gas, and coal for combustion-related activities [5]. Given this significant input, Russia's strategic behavior regarding the energy transition is important not only for the country itself, but also for the rest of the world.

There are several factors which define Russia's attitude towards the energy transition:

- Macroeconomics (including the role of hydrocarbon revenues for the sustainability of its economic system, speed of economic growth, and investment availability, as well as technological and financial sanctions);

- Institutional framework of the energy sector;

- Climate policy;

- Technology policy.

\section{Russian macroeconomics}

For Russia, as for many other resource-rich and energyexporting countries, the energy transition creates new longterm challenges, questioning the sustainability of the entire economy, which is highly dependent on hydrocarbon export revenues. Since the beginning of the 2000s, Russia has managed to increase energy exports dramatically: from 2000 to 2005 , exports grew by an unprecedented 56\% [4], exceeding the total energy exports of the USSR, providing an incredible acceleration of the national economy and strengthening the country's position on the international stage as an "energy superpower". But with the global financial-economic crises in 2008, energy export growth was halted. The post-crisis years of 2011-2014 saw still very high oil prices, but stagnant export volumes. Lack of petro-dollar revenues has resulted in GDP stagnation at an oil price of $110 \$ / \mathrm{bbl}$, which is clear evidence of deep structural economic problems. Oil and gas export revenues have recently declined from the heights of 2008-2012 under the impact of falling prices for hydrocarbons. Nonetheless, even in 2017, hydrocarbons provided $25 \%$ of GDP and $39 \%$ of the country's federal budget revenues, $65 \%$ of foreign earnings from exports, and almost a quarter of overall investments in the national economy [7].
Globally rising renewables targets and the transition towards a decarbonization paradigm are regarded in Russia as a significant threat to hydrocarbon export revenues, and thus to Russian economic security [8]. However, the global market balance is undergoing a fundamental shift, and the role of hydrocarbons will inevitably change during the next two decades. According to estimates by the Energy Research Institute of the Russian Academy of Sciences (ERI RAS), with the transformation of the global markets and reduced call for Russian hydrocarbons, the contribution of oil and gas to Russian GDP will decline by approximately half, from $31 \%$ in 2015 to $13-17 \%$ by 2040 (depending on the scenario) [4]. Therefore, climate-related policies that target a reduction in GHG emissions from hydrocarbons can substantially affect the Russian economy.

Domestic oil and gas demand does not provide any meaningful offset to this decline. After high growth rates (7-8\% per annum) in the first decade of this century, during the past few years Russia's GDP projections have been revised downward to $1-2 \%$ per annum due to the systemic economic crisis, international financial and technological sanctions, and unfavorable investment climate [9]. A stagnant economy means stagnant domestic energy demand, frozen domestic regulated prices, and low investment availability for new technology deployment. These factors, which obviously limit investment capacity, are exacerbated by financial sanctions and the weak domestic financial market, with very high cost of capital.

\section{Institutional design of the Russian energy sector}

Historically, the Russian energy sector has developed in an extremely centralized way. In the Soviet Union, statelevel single complex development plans (5-year plans) were accompanied by a hierarchical structuring of all the energy industries, managed from the "Center", with single transportation, export and storage infrastructure, and centralized dispatching. Despite the many market reforms in the 1990s, the institutional framework of the Russian energy sector today is still characterized by high corporate concentration and a lack of market mechanisms. Decentralization as a concept faces strong resistance from both the authorities and major business stakeholders. It is quite frequently regarded as a threat to the stability and reliability of the national energy system, and to national security.

The Russian electricity market, after a long process of reform, finally comprises a variety of different companies, both state- and privately owned. State-owned companies dominate: in the power generation sector, they control about $70 \%$ of capacity, and in the transmission sector they own all high-voltage grids in the country (220 kV and more) and almost all distribution grids as well. Thermal power plants provide about $63 \%$ of the total Russian electricity mix 
and are largely based on outdated technologies (just $25 \%$ of gas-fueled power plants have gas turbine or combinedcycle technology, and just $22 \%$ of coal-fired power plants use supercritical technologies). At the same time, the Russian centralized heat supply and combined heat and power plants (CHP) are very well developed. Almost every city in the country has a unified heat supply system (about 50,000 in total), and CHPs account for more than $50 \%$ of the total fossil-fueled installed capacity.

State-controlled companies produce more than $50 \%$ of the oil [10], and domestic prices for oil products are de facto regulated through artificial "freeze agreements", while the natural gas market is dominated by state-owned Gazprom, with gas prices for both residential and industrial consumers regulated by the government and currently frozen at the level of inflation [11]. Three decades after a command economy under the Soviet Union, low prices for energy in Russia are still regarded as a "public good", and any attempt to increase them sparks strong protests from consumers. The rather cheap energy does not create incentives for energy efficiency improvements, or for the modernization of existing assets with high specific fuel consumption.

The controversial and complicated institutional design of the Russian energy sector, with strong state regulation and some elements of market competition, creates unclear signals for participants. It is associated with high transaction costs, and thus represents one of the major obstacles to large-scale energy transition in the country.

\section{Russian climate policy}

Decarbonization is the main driver of energy transition globally. Individual regions, countries, or their associations set goals for reducing the carbon footprint in the energy sector and introduce mechanisms to stimulate this process, such as carbon taxes or emissions trading systems. According to the World Bank Group [12], 51 carbon pricing initiatives have been implemented or are scheduled for implementation in regional, national, and subnational jurisdictions. During the period from 2008 to 2017, the carbon content of electricity decreased by $50-100 \mathrm{~g} \mathrm{CO}_{2} / \mathrm{kWh}$ in the European Union, USA, Canada, China, Australia, and Kazakhstan, among other countries [13].

Despite this global trend, the climate agenda and the drive for decarbonization are not yet essential factors in the energy strategy of the Russian Federation. Indeed, the Paris Agreement is mentioned only once in the draft version of the "Russian Energy Strategy Up to 2035", a key document defining the country's strategic priorities in this critically important industry, which was submitted to the government by the Energy Ministry in 2015 but not approved until now: "In 2016, the Russian Federation signed the Paris Agreement, which included, among other, the development by 2020 of a strategy of socio-economic development with a low level of greenhouse gas emissions for the period until 2050. In order to minimize possible negative consequences for the Russian fuel and energy complex from the implementation of this agreement, an extremely weighted approach is needed to take some additional regulatory measures to counter climate change" [14]. This very cautious approach towards decarbonization is driven by several factors.

First, skepticism concerning the anthropogenic nature of climate change is prevalent among stakeholders, as senior representatives of the Russian Academy of Sciences and many state officials publicly express their doubts regarding the very concept of anthropogenically driven climate change. Second, following the economic downturn and economic restructuring in the 1990s, Russia has de facto sharply reduced GHG emissions. According to United Nations Framework Convention on Climate Change (UNFCCC) data, GHG emissions in 1998 compared to 1990 fell by $40.6 \%$, excluding land use, land-use change, and forestry (LULUCF), and by 50.9\% including LULUCF. From 1998 to 2008, GHG emissions rose much more slowly than GDPonly about $16 \%$ over 11 years [15]. Third, as of 2017, the Russian electricity sector has a lower carbon footprint (in terms of $\mathrm{g} \mathrm{CO}_{2}$ per $\mathrm{kWh}$ ) than, for example, Poland, Germany, Australia, China, India, Kazakhstan, the Arab countries of the Persian Gulf, the USA, Chile, and South Africa [13] - around 35\% of electricity is generated at carbon-free nuclear power plants and large hydropower plants, and $48 \%$ comes from gas [16], with gas gradually displacing petroleum products and coal in the fossil-fueled power plant fuel mix (the share of gas in fossil-fueled electricity generation increased from 69 to $74 \%$ in 2006-2017).

Obviously, the climate agreement affects Russia's prospects for fossil fuel exports (especially for coal exports, but natural gas exports might also be substantially affected by a further increase in emission reduction goals). Moreover, modeling shows that climate-related actions outside of Russia could cause Russia's GDP growth rate to decline by about half of a percentage point [17]. In addition, Russia faces the threat of market barriers for its exports of energy-intensive goods. Therefore, incentives to set ambitious national decarbonization targets are very low, especially assuming that these additional efforts would require significant investments, which are not available in light of the economic stagnation and financial sanctions, and would also require higher prices for energy, which is socially unacceptable.

This background explains why Russia has remained isolated from the global decarbonization trend for many years. Its participation in international environmental cooperation has always been determined primarily by external policy objectives. In Soviet times, participation in global environmental initiatives was a channel of collaboration with the West. In the 1990s, it was a means of integration into the 
international community and one of the major areas of cooperation with the USA. In the 2000s, Russia used the environmental agenda to gaining trade-offs from Western partners in order to attract foreign investment [18]. At present, an understanding of the potential benefits that may be reaped from the country's natural capital is slowly taking form among Russian political and business elites, so in the longer term, Russia's involvement in international environmental cooperation may increase. Meanwhile, the status quo is as follows: Russia signed the Paris Agreement in 2016, with voluntary obligations to limit anthropogenic GHG emissions to $70-75 \%$ of 1990 emissions by 2030 , provided that the role of forests is taken into account as much as possible. But even with this very low target, which is nearly guaranteed, Russia has not yet ratified the agreement. Potential non-ratification would not improve Russia's position (and would likely invite broader carbon adjustment measures from other regions). Diversification of the economy may help, but there is currently no clear path for its implementation.

\section{Technology policy}

While failing to give serious attention to climate policy, Russia is at the same time very sensitive to technology policy. The country's leadership realizes that Russia clearly faces the risk of falling behind in developing new energy technologies that will become standard throughout the world. This is the reason for strict requirements on equipment localization for renewable energy and smart grids, and numerous import substitution programs. At the same time, energy transition technologies are definitely not the main focus of Russian technology policy: in the key state document defining priorities in this area - the state program "Energy Development" approved in 2014 and amended in 2019-only "promotion of innovative and digital development of the fuel and energy complex" is mentioned as a target, together with all the new technologies in hydrocarbon production and processing; nothing at all is said concerning low-carbon technologies [19].

\section{Summing up Russia's approach to energy transition and its drivers}

The global "three D" drivers work differently in various countries, and Russia is a good example of just "1.5 D" actually being relevant: as shown above, the climate agenda is not relevant in Russia, while the competitiveness of the national economy and energy security are already provided by abundant cheap hydrocarbons (primarily natural gas). Thus, for Russia, technology policy and a desire to prevent the emergence of a large technology gap are the only truly important drivers of the energy transition. And among the "three D" pillars, decarbonization and, in part, decentralization are currently unacceptable to the country's leadership and major stakeholders, leaving it mainly up to digitalization, which has indeed recently become the major focus for Russian energy sector investment.

Nevertheless, despite this limited motivation to promote the energy transition in Russia, there are some areas where potential benefits are huge and which could create real value for the Russian economy and attract investments provided there were proper regulations in place. These key areas are as follows:

- Energy efficiency;

- Renewables;

- Decentralization and distributed energy resources;

- Digitalization;

- Hydrogen.

\section{Energy efficiency}

Factors related to Russia's cold climate, vast distances, overlarge raw material structure, poor economic organization, and significant technological backwardness have resulted in its high-energy-intensity GDP- 1.5 times the world average and that of the USA, and twice that of the leading European countries [4]. There is a substantial energy efficiency gap in almost all industrial technologies, not only with regard to the best available technologies, but also with "actual consumption abroad". Even with comparatively low fuel and energy prices, the share of fuel and energy costs as a percentage of overall production costs is higher in Russia than in the developed and many developing countries [20]. Before the 2009 economic crisis, Russia was one of the world leaders in terms of GDP energy intensity reduction, and the gap between Russia and developed countries was narrowing dramatically-a 40\% reduction in GDP energy intensity was achieved from 1998 to 2008; however, since 2009, this reduction has slowed and even reversed. According to Bashmakov [19, 21], GDP energy intensity in Russia in 2017 was just 10\% lower than in 2007 (at the same time, the initial energy efficiency target set in 2008 was a $40 \%$ decline in GDP energy intensity by 2020). Substantial federal budget subsidies were allocated, but very limited change occurred, and as a result the initial target was scaled back significantly, to $9.41 \%$, and federal funding was discontinued [22].

Obviously, for such an energy-intensive economy, issues such as energy efficiency and conservation are key concerns for energy transition: according to IEA analyses, $30 \%$ of Russian primary energy consumption and enormous amounts of hydrocarbons ( $180 \mathrm{bcm}$ of gas, $600 \mathrm{~kb} / \mathrm{d}$ of oil and oil products, and more than 50 Mtce of coal per annum) could be saved if efficiency measures comparable to OECD targets were applied [23]. The main role in reducing the 
growth of energy consumption could be provided by structural energy conservation (changing the industrial and product structure of the economy), with an increase in the share of non-energy-intensive industries and products. The next most important factor in constraining the growth of energy consumption is technical energy conservation, which can provide total energy savings of $25-40 \%$. However, it will be extremely difficult to close this the gap with the OECD countries-it actually widens due to the lack of investment potential for rapid asset renewal and energy efficiency funding. If we add to this the continuing administrative barriers and, most importantly, the unavailability of "long money" and credits for energy efficiency projects for small market participants, coupled with the persistence of relatively low natural gas prices in the long term, Russia remains stuck in a state of high energy intensity. Robust policies are needed to change this pattern, accompanied by a substantial increase in energy prices; potential benefits. however, are similarly significant.

\section{Renewables}

The Russian energy balance is strongly dominated by fossil fuels, with natural gas providing $53 \%$ of total primary energy demand, and coal and oil-based liquid fuels each accounting for $18 \%$. Carbon-free sources of energy are represented primarily by large-scale hydro and nuclear power (which enjoy strong state support). The total share of renewables (including hydro, solar, wind, biomass, and geothermal) was just $3.2 \%$ of Russia's primary energy consumption in 2015. By the end of 2015, total installed renewable power generation capacity was $53.5 \mathrm{GW}$, representing about $20 \%$ of Russia's total installed power generation capacity $(253 \mathrm{GW})$, with hydropower providing nearly all of this capacity $(51.5 \mathrm{GW})$, followed by bioenergy $(1.35 \mathrm{GW})$. The installed capacity for solar and onshore wind amounted to $460 \mathrm{MW}$ and $111 \mathrm{MW}$, respectively, as of 2015 [24].

According to the draft Energy Strategy of Russia for the period up to 2035 [14], the renewable energy share of Russia's total primary energy consumption should increase from 3.2 to $4.9 \%$ by 2035 . This includes Russia's approved plan to expand its total solar photovoltaics (PV), onshore wind, and geothermal capacity to $5.9 \mathrm{GW}$ by the end of 2024. The foundation for the growth of renewables in Russia is Decree 449, passed in 2013, which created a legal framework establishing a renewable energy capacity system for the country. The decree is designed to encourage the development of renewable energy, focusing in particular on wind and solar PV, and to a lesser extent on small-scale hydropower. The legislation sets out the terms for participation in the country's renewables capacity markets. Under this system, energy developers of projects with an output of at least 5 MW can bid for capacity supply contracts with Russia's Administrator of the Trading System in annual tenders. Winning suppliers are paid for both the capacity they add to the energy system and the energy they supply, based on long-term 15-year contracts with fixed tariffs. This regulation sets a legal and regulatory environment that allows developers to commercialize capacity as a separate commodity from the power itself, and ensures the economic attractiveness of these projects for the investors. In return, renewables developers are expected to ensure they can provide the promised capacity, on the right timeline, and with sufficient localization of the equipment [25].

Since then, annual renewable capacity additions rose from $57 \mathrm{MW}$ in 2015 to $376 \mathrm{MW}$ in 2018 (320 MW solar, $56 \mathrm{MW}$ wind). What is more important is the significant decline in capital expenditures in renewables auctions during the past 2 years, by $35 \%$ for wind and $31 \%$ for solar, according to the Energy Ministry [24]. This process was not smooth; some capacity auction rounds have struggled to attract bids for a number of reasons, just over $2 \mathrm{GW}$ of renewable capacity was awarded in tenders between 2013 and 2016, while the 2017 auction resulted in a total of $2.2 \mathrm{GW}$ of wind, solar, and small hydro awarded in a single round, and in 2018, $1.08 \mathrm{GW}$ of capacity was allocated among 39 projects. In 2017, five waste-to-energy projects were also introduced to the capacity market scheme, with a total capacity of 335 MW. But in 2018, the tender for waste energy capacity failed because of the strict new requirements for bidders to provide performance guarantees.

As technology policy is the main driver of Russia's interest in renewables, the country is focused first of all on building its own renewables manufacturing capacity. Russia has set a fairly high level of local content required to qualify for the highest tariff rates, an essential component of the longterm feasibility of many Russian renewables projects. The percentage of Russian-made equipment required to avoid tariff penalties was relatively modest in the early days of the auction system, but has now risen to $65 \%$ for wind farms and small hydro and $70 \%$ for solar until 2020, with the long-term target of localization set by the government at $80 \%$. These high levels have been behind several tenders, especially in wind farm development, for which there has been little to no Russian-made equipment. The requirements have encouraged foreign firms to partner with Russian power companies and manufacturers. Several international joint ventures have been established, including Fortum and state-owned technology investor Rusnano's wind investment fund, and WRS Bashni, a partnership between Spanish developer Windar Renovables, Rusnano, and the Russian steel firm Severstal. Wind equipment was localized by Vestas Manufacturing Rus in the Nizhny Novgorod region, while Siemens Gamesa Renewable Energy (SGRE) and Lagerwey are also entering the Russian market [25]. 
The problem is that the current support mechanism will expire in 2024-Russia's unambitious renewables share targets and ambitious localization targets will be nearly fulfilled by this time - and the influx of foreign renewables developers may stop if no new incentives for renewables are created. However, in order to create these incentives, the Russian government should first determine the long-term role of renewables in its energy balance, which is quite difficult to do without a decarbonization agenda: as the country with the world's largest natural gas reserves and the second largest reserves of thermal coal, Russia does not see real value in a transition from fossil fuels to zero-carbon energy sources. Despite the country's massive potential in wind and solar resources and the virtually limitless land available for development, the availability of oil, gas, and coal is suppressing the development of clean energy. Diversifying this energy mix towards carbon-free energy sources is a challenging task: low prices for hydrocarbons and the unfavorable geographical dispersal of potential renewable resources from the point of their utilization (mainly concentrated in unpopulated areas with a long distance to the center of consumption), together with their comparatively high cost (e.g. low demand for new renewable capacity and high requirements for localization, resulting in high, uncompetitive perunit cost) hinder the development of these energy sources in Russia.

According to the International Renewable Energy Agency (IRENA) [23], Russia theoretically has the potential to increase its share of renewables from 4.9 to $11.3 \%$ of total primary energy consumption by 2030 . However, without reassessment of its energy strategy priorities and wider transformation of its energy system, this may be difficult to achieve.

\section{Decentralization and distributed energy resource potential in Russia's centralized power system}

Historically, the Russian energy system has developed in an extremely centralized way: Russia has one of the world's largest national centralized power systems with a single dispatch control-as of 2017, the total length of its trunk networks was over $140,000 \mathrm{~km}$, with over 2 million $\mathrm{km}$ of distribution networks and $246.9 \mathrm{GW}$ installed capacity of power plants. This energy system was created and developed on a hierarchical basis with centralized long-term planning bodies. The centralized model has been the basis of the energy strategy for decades, while distributed energy resources (DER), including microgrids on renewables, are developing slowly and only in remote and isolated areas. A significant role for distributed generation has been significant only in the remote areas of the Far East, Siberia, and the Arctic, which are too expensive to connect to the unified national network. However, the incorporation of DER within the centralized system has begun, as is the case elsewhere in the world.

Decentralization of the power sector began when economies of scale in power generation ceased to be significant globally due to technological improvements. The catalyst for this change was the emergence of gas turbine and reciprocating gas engine technologies in the 1980s. The reciprocating gas engine global market showed steady growth (compound annual growth rate [CAGR] of 17\%) through the late 2000s [26]. For example, in the USA, distributed generation has played a role in the electric power sector for several decades [27]. Historically, these DER have consisted of dispatchable resources; however, the recent increase in non-dispatchable PV capacity marks a change in this trend. The Bloomberg New Energy Finance (BNEF) forecast shows that by 2040, the decentralization ratio will exceed $15 \%$ in eight countries (as was seen in Germany in 2017) [28]. Global annual distributed generation capacity additions have already exceeded centralized ones, and non-generation types of DER have even more potential than distributed generation (in the USA in 2014, demand response and energy efficiency potential [37 GW] was higher than CHP [18 GW] and solar [8 GW]) [27]. Similar to other countries, integration of DER into the Russian electricity sector was noticeable in the 2000s, but over the past 17 years has been limited to distributed generation only. The development of this process in Russia is driven not by global climate agenda or energy independence concerns, but by economic considerations of the largest electricity consumers. Almost all Russian large industrial companies (including oil and gas industry leaders like Gazprom, Rosneft, Lukoil, Novatek, and Sakhalin Energy) develop their own distributed generation projects in order to obtain a more affordable power supply.

Micro-generation using renewables for households in Russia is still largely confined to enthusiasts. There are just a few cases in place in several regions, all driven almost completely by economic expediency factors.

Non-generation types of DER in Russia are in the very early phase of development. Demand response technologies began to emerge in 2016-2017, but only a small proportion of power consumption was affected (54 MW in the second price zone of the wholesale power market, or $0.1 \%$ of total capacity in this zone). Demand response in the retail electricity market is in the experimental stage.

However, the potential for DER in Russia is significant. According to a study by the Skolkovo Energy Center [29], this potential can easily cover over half of the generation capacity need (about $36 \mathrm{GW}$ by 2035). The most promising type of DER in Russia is distributed co-generation $(\sim 17 \mathrm{GW})$. On-site self-generation units for electricity consumers are able to provide an additional $\sim 13 \mathrm{GW}$, demand response up to $4 \mathrm{GW}$, energy-efficient technologies $1.5 \mathrm{GW}$, 
and rooftop PV systems $0.6 \mathrm{GW}$. Full use of a DER scenario shows the possibility of closing the entire gap by 2035 .

In order to stimulate the maximum use of DER technologies, systemic architecture and policy changes are needed in the Russian power sector, balancing the interests of new players with the existing model. A consistent reasonable combination of centralized generation and DER seems the most effective approach. To implement such a combination, principles and market mechanisms must be developed for the integration of the centralized and decentralized parts and to ensure their reliable joint operation.

\section{Digitalization as government priority}

Digitalization of the energy sector as a whole, and of the power sector in particular, is part of a global trend, which means that rapidly developing digital technologies penetrate the economy. For the power sector, it creates new opportunities-after all, it is becoming increasingly difficult to manage power systems with a high ratio of intermittent renewables. According to the IEA, investments in digital technologies globally are higher than in gas-fired power generation [30].

Russian authorities regard the digital transformation of the energy sector as a key technological challenge (also keeping in mind the high dependence on imports for all high-tech equipment and the potential threat of sanctions, which could create serious risks for national energy security), which is why digitalization has become the main driver of Russia's energy transition. In 2018, Vladimir Putin signed a decree establishing a special "Digital Economy" state program, with energy infrastructure mentioned as a key component. The Energy Ministry has also developed its special "Digital Energy" project focused primarily on digitalization of regulation, coordination, and creation of the whole institutional framework for the wide-scale introduction of digital technologies in the energy sector. According to the "Digital Transformation Strategy" of the state-owned power grid company Rosseti, the improved reliability of the power supply to consumers and the increased availability of electric grid infrastructure are among the effects of digital transformation.

Systematic and sequential digital transformation reduces the time and facilitates the process of technological connection, reduces the cost of maintenance and repair, increases the efficiency of grid management, reduces the number and duration of outages, and increases the service life of equipment. This improvement is possible because of more effective accident prevention and quick response to incidents owing to accurate information about their localization, equipment maintenance, and optimization of equipment operation modes in normal and emergency modes, ensuring prompt restoration of the power supply, including selective technology. Significant budgets are allocated for research and development (R\&D) and localization of equipment, and for the development of redesign plans for the existing electricity networks, but this process is still in a very early stage, and it is difficult to assess its real results.

\section{Hydrogen}

Russia remains isolated from the international community and partnerships among countries in developing hydrogen technologies. First of all, as mentioned earlier, this is explained by the fact that the climate change agenda and decarbonization still play a minor role in Russian energy strategy, which significantly hinders the development of all low-carbon technologies (renewables, energy efficiency, electric transport, etc.). At the same time, Russia has abundant resources for producing hydrogen, and there is some R\&D activity in this area (mostly, however, far from commercialization) and prospective domestic demand niches for hydrogen.

\section{Conclusion: a new strategy is needed in order to adapt to the energy transition}

Russia's attitude towards the energy transition is quite controversial: trying to introduce in a traditional centralized manner some components of this trend. First, with regard to new technologies, the country is essentially refusing to accept the main driver of the trend-the decarbonization agenda. Existing strategic documents (primarily a draft version of the "Russian Energy Strategy Up to 2035", which was submitted to the government by the Energy Ministry in 2015, but not approved until now [14]) do not take the energy transition into account. Nevertheless, at a certain point, the country will have to develop a long-term vision for both its domestic energy market development and its export strategy in order to adapt to the profound transformation of the global energy system.

Open Access This article is distributed under the terms of the Creative Commons Attribution 4.0 International License (http://creativeco mmons.org/licenses/by/4.0/), which permits unrestricted use, distribution, and reproduction in any medium, provided you give appropriate credit to the original author(s) and the source, provide a link to the Creative Commons license, and indicate if changes were made.

\section{References}

1. Smil, V.: Energy and civilization: a history. MIT Press, US (2018)

2. Federal Ministry of Economics and Technology, Federal Ministry for the Environment, Nature Conservation and Nuclear Safety: Energy concept for an environmentally sound, reliable 
and affordable energy supply. Organization for security and cooperation in Europe. https://www.osce.org/eea/101047 (2013). Accessed 22 Apr 2019

3. Trüby, J., Schiffer, H.W.: A review of the German energy transition: taking stock, looking ahead, and drawing conclusions for the Middle East and North Africa. Energy transitions 2, 1-14. https ://doi.org/10.1007/s41825-018-0010-2 (2018). Accessed 22 Apr 2019

4. ERI RAS: Global and Russian energy outlook up to 2040. ERI RAS, AC RF. https://www.eriras.ru/files/forecast_2016.pdf (2016). Accessed 22 Apr 2019

5. BP: BP statistical review of world energy. 67 th edition. https:// www.bp.com/en/global/corporate/energy-economics/statistica 1-review-of-world-energy.html (2018). Accessed 22 Apr 2019

6. International Energy Agency. Coal 2018: analysis and forecasts to 2023. OECD/IEA. https://www.iea.org/coal2018 (2018). Accessed 22 Apr 2019

7. Trading Economics: Russia GDP growth rate. https://tradingeco nomics.com/russia/gdp-growth (2018). Accessed 22 Apr 2019

8. Presidential Decree of May 13, 2017 No. 208 "On the Strategy of Economic Security of the Russian Federation for the Period until 2030" (Russian). https://www.garant.ru/products/ipo/prime /doc/71572608/ (2017). Accessed 22 Apr 2019

9. World Bank Group: Modest growth ahead. 39 Russia economic report, May 2018. Open knowledge repository. https://openk nowledge.worldbank.org/bitstream/handle/10986/29913/12725 4-WP-PUBLIC-ADD-SERIES-JunefinalRussiaEconomicRe portENG.pdf?sequence=1\&isAllowed=y (2018). Accessed 22 Apr 2019

10. Mitrova T., Grushevenko E., Malov A. The future of Russian oil production: life under sanctions. SKOLKOVO Energy Centre. https://energy.skolkovo.ru/downloads/documents/SEneC/resea rch04-en.pdf (2018). Accessed 22 Apr 2019

11. Henderson J., Mitrova T. Natural gas pricing in Russia: between regulation and markets. (Russian). SKOLKOVO Energy Centre. https://energy.skolkovo.ru/downloads/documents/SEneC/resea rch02.pdf (2017). Accessed 22 Apr 2019

12. Ramstein, C., Goyal, R., Gray, S., Kallhauge, A.C., Lam, L., Klein, N., Wong, L., Quant, M., Nierop, S., Berg, T., Leuschner, P.: World Bank and Ecofys: State and trends of carbon pricing 2018. World Bank, Washington, DC (2018). https://doi. org/10.1596/978-1-4648-1292-7

13. Staffell, I., Jansen, M., Chase, A., Cotton, E., Lewis, C.: Energy revolution: global outlook. Selby, Drax (2018)

14. Ministry of Energy of Russian Federation: Draft Energy Strategy Up to 2035 (Russian). https://minenergo.gov.ru/node/1920 (2017). Accessed 22 Apr 2019

15. Summary of GHG Emissions for Russian Federation/UNFCCC. Energy Agency (IEA): electricity information. IEA/OECD Publications, Paris. https://di.unfccc.int/ghg_profiles/annexOne/RUS/ RUS_ghg_profile.pdfInternational (2018). Accessed 22 Apr 2019

16. Makarov, I. A., Chen H. Y., Paltsev S.: Finding itself in the postParis World: Russia in the new global energy landscape. MIT
CEEPR working papers. CEEPR. MIT Center for Energy and Environmental Policy Research, 2017. No. WP-2017-022. http:// ceepr.mit.edu/publications/working-papers/675 (2017). Accessed 22 Apr 2019

17. Makarov, I.A.: Russia's participation in international environmental cooperation. J. Strateg. Anal. 40(6), 536-546 (2016). https:// doi.org/10.1080/09700161.2016.1224062

18. Ministry of Energy of Russian Federation: State strategy "Energy Development" (Russian). https://minenergo.gov.ru/node/323 (2019). Accessed 22 Apr 2019

19. Bashmakov I. Driving industrial energy efficiency in Russia. Moscow, March 2013. http://www.cenef.ru/file/Idustry-eng.pdf (2013). Accessed 22 Apr 2019

20. International Energy Agency (IEA): World Energy Outlook 2011. IEA/OECD Publications, Paris (2011)

21. Bashmakov, I.: What happens to the energy intensity of Russia's GDP? (Russian). Ecol. Bull. Russ. 7, 8 (2018)

22. Ministry of Economic Development of the Russian Federation: State report on the state of energy savings and energy efficiency in the Russian Federation in 2017 (Russian). Moscow (2018)

23. International Renewable Energy Agency (IRENA): Renewable energy prospects for the Russian Federation (REmap working paper). IRENA. https://www.irena.org/publications/2017/Apr/ Renewable-Energy-Prospects-for-the-Russian-Federation-REmap -working-paper (2017). Accessed 22 Apr 2019

24. Ministry of Energy of the Russian Federation: Presentation on the results of the fuel and energy complex functioning in 2018 and its targets for 2019 (Russian). Moscow (2019)

25. Power Technology: Is Russia finally ready to embrace renewable energy? https://www.power-technology.com/features/russia-renew able-energy/ (2018). Accessed 22 Apr 2019

26. Diesel \& Gas Turbine Worldwide. 30th power generation order survey. https://dieselgasturbine.com/market-surveys (2006). Accessed 22 Apr 2019

27. Rhodium Group: What is it worth? The state of the art in valuing distributed energy resources. https://rhg.com/research/what-isit-worth-the-state-of-the-art-in-valuing-distributed-energy-resou rces/ (2017). Accessed 22 Apr 2019

28. Bloomberg New Energy Finance: New energy outlook. https:// about.bnef.com/new-energy-outlook (2017). Accessed 22 Apr 2019

29. Khokhlov, A., Melnikov, Y., Veselov, F., Kholkin, D., Datsko, K.: Distributed energy resources in Russia: development potential. SKOLKOVO Energy Centre. https://energy.skolkovo.ru/ downloads/documents/SEneC/Research/SKOLKOVO_EneC_ DER_2018.10.09_Eng.pdf (2018). Accessed 22 Apr 2019

30. International Energy Agency (IEA): Status of power system transformation — advanced power plant flexibility. Executive summary. IEA/OECD Publications, Paris. https://webstore.iea.org/downl oad/summary/1041 (2018). Accessed 22 Apr 2019 